\title{
CLEAN AND HEALTHY LIFESTYLE BEHAVIORS AND HEALTHY HOUSING INFLUENCED THE INCIDENT OF ACUTE RESPIRATORY INFECTION IN CHILDHOOD
}

\author{
MUHAMMAD EL KAUTSAR ${ }^{1}$, NILAM ANGGRAENI ${ }^{1}$, VIVI PERMATA SARI ${ }^{1}$, RIBKA B. A MBOE ${ }^{1 *}$, ANINDYA \\ WIDYASARI ${ }^{1}$, ZAHWA AFDHILANI AZWAN ${ }^{1}$, ATHIYAH AMATILLAH ${ }^{1}$, PRISCILLIA IVANA JIE ${ }^{1}$
}

\begin{abstract}
Introduction: Based on preliminary surveys in this study, it was found $86.7 \%$ of respondents suffered from accute respiratory infection experienced 4 times reinfection within 3 months and 50\% of respondents rarely consumed balanced nutritious food.
\end{abstract}

Aims: to find the correlation between clean and healthy lifestyle behaviours, healthy housing and the frequency of accute respiratory infection in children under the age of 1-4 years.

Method: a cross-sectional study was used by involving mothers or caregivers with infants aged 1-4 years in Malang Regency. A questionnaire was applied as research instrument.

Result: Statistical analysis shows that there is a significant correlation between family members who smoke ( $p$-value $=0.021$ ) and the level of home density ( $p$-value=0.03) with the frequency of acute respiratory tract infections in toddlers. While the relationship of other variables such as the sex of children under five ( $p$-value $=0.799)$, clean and healthy lifestyle behaviour: delivery at primary health care ( $p$-value $=0.084)$, exclusive breastfeeding ( $p$-value $=0.940)$, routinely visiting Integrated Healthcare Center ( $p$-value=0.396), hand washing behaviour ( $p$-value=0.523), consuming healthy food ( $p$ value $=0.247)$, and infant's activity ( $p$-value $=0.096)$, healthy housing: ventilation ( $p$-value $=0.396)$ and lighting ( $p$-value $=0.767$ ) have no a significant correlation with incident of accute respiratory infection in infants.

Conclusion: There is a correlation between family members who smoke and the level of home density with the frequency of accute respiratory infection in children under the age of 1-4 years

Keywords: clean and healthy lifestyle behaviours, healthy housing, frequently of accute respiratory infection, children, health behaviour.

Received: 01 November, 2020

Accepted: 25 December, 2020

DOI: https://doi.org/10.3329/bjm.v32i1.51090

\section{Introduction}

Acute Respiratory Infection is a disease mostly affectedon children in the age of 5-14 years, the prevalence of infected between men and women seems almost the same, namely 510,714 and 506,576 respectively. Housing is an influential factor, where more people in urban areas are infected than in rural areas ${ }^{1}$. This disease is caused by a small substance (smaller than bacteria) - called virus - that causes infection and transmitte from one person to another through coughing or sneezing ${ }^{2}$.

Clean and Healthy Behavior are all attitudes towards health carried out on the basis of personal awareness which makes the family and all members able to help themselves in the health sector and have an active role in community activities. The main purpose of making the Clean and Healthy Behavior movement is to improve the quality of health through the process of awakening people from ignorance ${ }^{3}$.

According to WHO (2001), a house is a physical structure or building for shelter, where the environment is useful for physical and spiritual health and social conditions both for the health of families and individuals ${ }^{4}$. Healthy housing have criteria to prevent the occurrence of acute respiratory tract infections consisting of: the walls of the house, the floor of the house, air ventilation, residential density and lighting must be in accordance with the requirements of a healthy home so that humidity does not occur. Healthy housing factors can prevent the growth of a variety of bacteria and pneumonia viruses ${ }^{5}$.

1. Resident at Faculty of Medicine, Universitas Airlangga, Surabaya, Indonesia

Corresponding Author: Ribka B. A. Mboe, Faculty of Medicine, Universitas Airlangga, Surabaya, Indonesia, Campus A, J1. Mayjen Prof. Dr. Moestopo 47, Surabaya, Indonesia (Zip Code: 60131). Email: ribkamboe@gmail.com

Bangladesh J Medicine 2021; 32 : 19-24 
Based on preliminary survey, approximately $86.7 \%$ of respondents suffered from acute respiratory infections 4 times in the last 3 months, and $50 \%$ of them consumed balanced nutritious food in low levels. The study aims to find the relationship between clean and Healthy Behavior, Healthy Housing and the frequency of accute respiratory infaction in children under the age of 1-4 years.

\section{Method}

Participant

A cross sectional with observational analytic approach was used in this study. The population was children aged under 5 years in Sumber Mlaten sub-village, Kalirejo sub-district, Lawang sub-district, East Java in 2019. The sample was taken using the total sampling method and meets the inclusion criteria which include: families of children aged 1-4 years who are willing to become respondents (mother/caregiver/other family), present during data collection.

\section{Data Collection and Analysis}

The research instrument was a questionnaire that had been tested for validity which included data on parental education, parental occupation, and sex of children under five years, infection status, clean and healthy lifestyle behaviours, and criteria for a healthy home referring to the Republic of Indonesia Ministry of Health (2016). The research period was from 8 December 2019 to 14 December 2019.

The data analyzed using a bivariate test with chi-square test and contingency coflication test to determine the correlation between clean and healthy lifestyle behaviours, Healthy Homes and accute respiratory infection in Children aged under five years. The data was analysed using statistical software program Statistical Package for the Social Science (SPSS) version 17.0 (SPSS.Inc., Chicago, IL).

Ethics Statement

This study was approved by the Ethics Committee of the Faculty of Medicine, Universitas Airlangga, Surabaya, Indonesia.

\section{Result}

The socio-demographic data included basic variables of mother or cargiver and children. Participants who have aged between 18-35 years and having primary school history have the percentage as much as $60.8 \%$ and $41.2 \%$, respectively. Meanwhile, the number of participants were mostly unemployed status about $82.4 \%$. The highest children age in this study was 2 years, namely $35.3 \%$ and female's children were the majority of children which counted as many as $56.9 \%$. The immunization status were dominated by children who have completed immunization status, namely $94.1 \%$.

Table 1 represented three variable which divided into clean and healthy lifestyle behaviours, healthy housing and incidence of accute respiratory infection in children within 3 months. According to clean and healthy lifestyle behaviours, it revealed that about $98 \%$ of participants visited primary health care as the method to deliver their children, $52.9 \%$ of paticipants have no given exclusive breastfeeding to their children. Moreover, approximately $84.3 \%$ of participants were routinely visiting integrated healthcare center, $68.8 \%$ of participants had gotten used to washing their hands using clean water. All participants declared that they had provided enough nutrition for their children (100\%) and almost all participants have a settled job (86.3\%). The smoking at home was done by $76.5 \%$ of

Table 1

The distribution of clean and healthy lifestyle behaviours, healthy housing, and accute respiratory infection

\begin{tabular}{|c|c|c|c|c|}
\hline \multirow[b]{2}{*}{ Clean and healthy lifestyle Behaviours } & \multicolumn{2}{|c|}{ Yes } & \multicolumn{2}{|c|}{ No } \\
\hline & $\mathrm{n}$ & $\%$ & $\mathrm{n}$ & $\%$ \\
\hline Delivery at primary health care & 50 & 98 & 1 & 2 \\
\hline Exclusive breastfeeding & 24 & 47.1 & 27 & 52.9 \\
\hline Regularly visiting Integrated Healthcare Center & 43 & 84.3 & 8 & 15.7 \\
\hline Wash hand behaviour & 35 & 68.6 & 16 & 31.4 \\
\hline Consuming healthy food & 51 & 86.3 & 7 & 13.7 \\
\hline Exercise & 44 & 86.3 & 7 & 13.7 \\
\hline Smoking at home & 39 & 76.5 & 12 & 23.5 \\
\hline \multicolumn{5}{|l|}{ Healthy Housing } \\
\hline Good Lighting & 46 & 90.2 & 5 & 9.8 \\
\hline Ceramic floor & 48 & 94.1 & 3 & 5.9 \\
\hline Room Ventilation $>10 \%$ & 8 & 15.7 & 43 & 84.3 \\
\hline Large of home $>8 \mathrm{~m}^{2} /$ person & 15 & 29.4 & 36 & 70.6 \\
\hline Accute respiratory infection in children within 3 months & 38 & 74.5 & 13 & 25.5 \\
\hline
\end{tabular}


participants. Healthy housing consisted by several factors, including natural lighting to the room which experienced by $90.2 \%$ of participant, floor of housing using tiles or ceramics had have by $94.1 \%$. Furthermore, as much as $84.3 \%$ of house has ventilation area $<10 \%$, and density $<8 \mathrm{~m}^{2} /$ person was $70.6 \%$.

Table-II

Statistical Analysis between variables

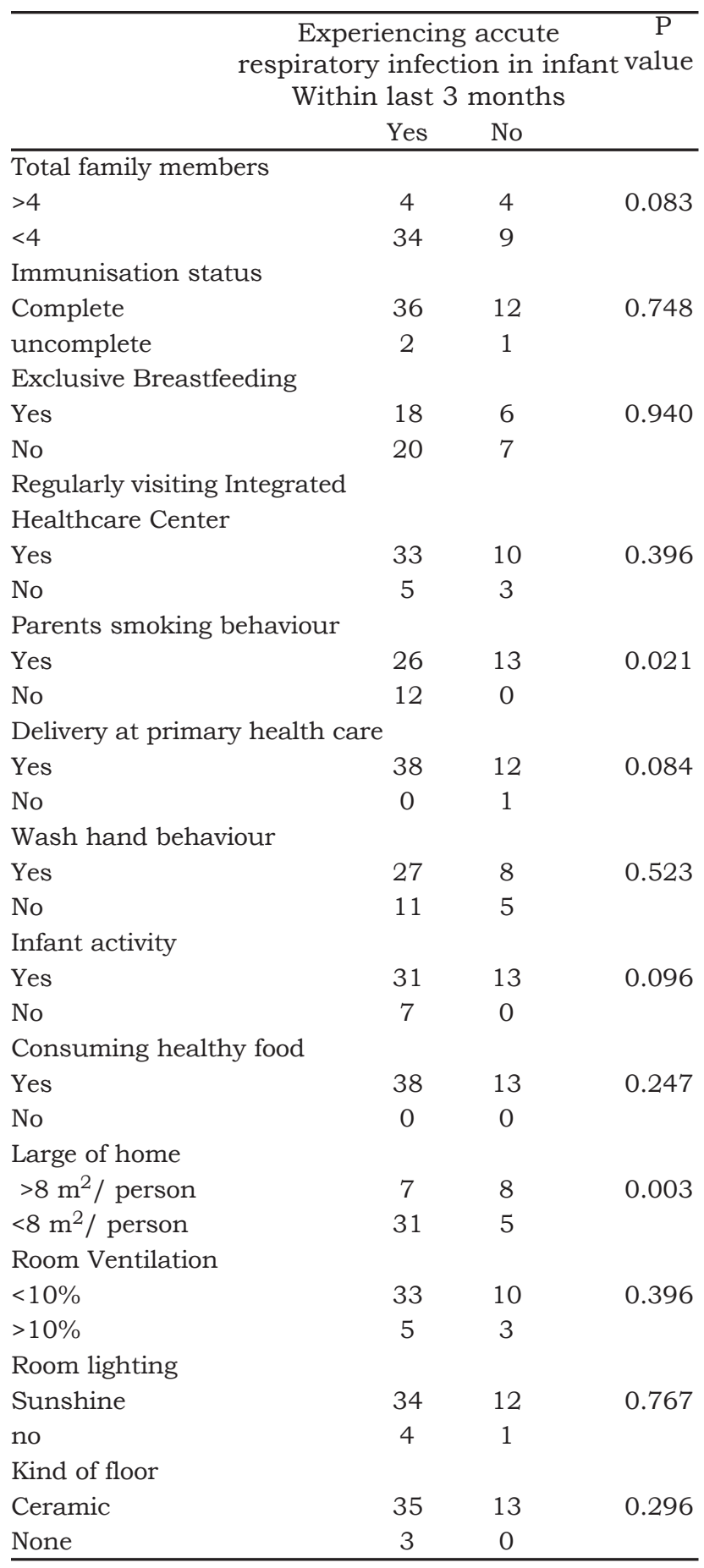

Bivariate analysis shows several factors associated with incident of accute respiratory infection in children aged 1-4 years (table 2). Parents who have smoked habit at home were more likely to increase the incident of accute respiratory infection in children compared to parents who had no smoked ( $\mathrm{p}$-value $=0.021$ ). Further, population density which was $<8 \mathrm{~m}^{2} /$ person, was more likely to increase the incident of accute respiratory infection in children compared to population density under $8 \mathrm{~m}^{2} /$ person $(\mathrm{p}$-value $=0.003)$. Whereas, variables related to children, such as total family members, immunization status, excusive breastfeeding and regularly visiting integrated healthcare center showed no correlation with the incident of of accute respiratory infection as the p-values were above the minimum standart, namely 0.083, 0.748, 0.940, 0.396, repectively. With regard to clean and healthy lifestyle behaviors variables, included: delivery at primary healthcare, washing hand, children activity, and consuming healthy food were less likely affected on the incident of of accute respiratory infection, which recorded p-value as much as 0.084, 0.523, 0.096, 0.247 , respectively. While, other healthy housing components, such as: room ventilation, room lighting, kind of floor have less likely significant correlation he incident of of accute respiratory infection, which the p-value were 0.396, 0.767, 0.296, respectively.

\section{Discussion}

Bivariate analysis showed that there was no significant relationship between hands washing behavior with the incidence of acute respiratory infections in children aged 1-4 years. This is in accordance with previous studies which produced a significant relationship between the incidences of acute respiratory infections with hand washing behavior ${ }^{6}$. Acute respiratory infections is the leading cause of death for children under five and hand washing habits can reduce respiratory infections by more than $50 \%{ }^{7,8}$.

We found as many as 31 children under five (61\%) had acute respiratory infections in the last 3 months who actively played both outside and inside the house. The finding indicates that there is no positive effect of playing activity with the incidence of acute respiratory infections in children under the age of 1-4 years. This is contrast with study that revealed a relationship between physical activity and morbidity, especially in the respiratory tract. The results of the study explained that subjects who did less activity were more susceptible to illness or often experienced pain compared to those who did many activities ${ }^{9}$. Regular physical activity is one way to maintain the immune system. Various studies have confirmed the beneficial effect of exercise activities on the components of the 
immune system. Regular physical activity also teaches the body to distribute blood better to muscles during activity $^{10}$. Physical activity and regular exercise and sufficient quantities, can help maintain optimal health for those concerned ${ }^{11}$.

The results showed that there was no significant influence between regularly visiting integrated healthcare center and acute respiratory infection in children under five in Sumber Mlaten Hamlet. This contradics with other studies that the incidence of acute respiratory infection in infants and regular visiting to integrated healthcare center have a signification of attachment ${ }^{12}$. Visiting integrated healthcare center is a form of Community-Based Health Efforts which manage and organize from, by, for and with the community in organizing health development, in order to empower the community and provide facilities to the community in obtaining basic health services. To accelerate the reduction in maternal and infant mortality rates ${ }^{13}$.

In this study, we found that the correlation between breastfeeding and acute respiratory infection was not significant. The results of this study are consistent with research in 2011 which showed that there was no relationship between exclusive breastfeeding and the incidence of acute respiratory infection in children aged 6 months to 24 months ${ }^{14}$. However, this study differs from other studies that there is a relationship between duration of exclusive breastfeeding exclusively with acute respiratory infections ${ }^{15}$. Breastfeeding has a protective effect of acute respiratory infection during the first year, but with increasing age of children under five years the level of immunoglobulin in breast milk will decrease so that if breastfeeding is given longer does not have much effect on body resistance to overcome microorganisms that cause acute respiratory infection ${ }^{16}$.

Smoking habits of parents showed highly likely affected the incident of acute respiratory infection in children as exposuring to cigarette smoke. This data is supported by previous studies that shows that there is a positive influence between exposure to cigarette smoke to acute respiratory infection in children under five ${ }^{17-19}$. Basically, smoking is one of the risk factors for acute respiratory infection in children under five, especially in East Java which had prevalence of acute respiratory infection at $6.4 \%$, while in Malang Regency the prevalence of acute respiratori infection was $4.3 \%{ }^{20}$. According to WHO (2008), the adverse effects of cigarette smoke on Passive smokers are greater than active smokers. Sidestream smoke or side smoke caused by the activity of passive smokers, is proven to contain more tobacco burners than mainstream smoke. This side smoke is proven to contain carbon monoxide 5 times larger, tar and nicotine 3 times, ammonia 46 times, nickel 3 times, nitrosamine as a cause of cancer levels reached 50 times greater in side smoke compared with the main smoke levels ${ }^{4}$.

These results indicate no significant effect on childbirth in health professionals and the incidence of acute respiratory infection in children under five. Women treated by traditional healers do not tend to get good early breastfeeding initiation so that neonates can lose important nutrients in clostrum which may cause health problems in the future ${ }^{21}$. Childbirth performed by health professionals, doctors, midwives or paramedics has a stake in the prevention of infections and other hazards that can threaten the safety of babies and mothers ${ }^{13}$ placenta does not come out, bleeding and infant death. However, due to ignorance of information, participants did not realize that the impact was very dangerous to their health ${ }^{22}$.

Population density in house has significant association with incident of acute resoiratory infection in children and another have proven the similar result as this finding ${ }^{23}$. Mostly of respiratory problems, such as acute respiratory infection, were affected with overcrowding, indoor and poor condition of the houses ${ }^{23}$.

The results of the bivariate interpreted that there is no significant correlation between lighting with acute respiratory infection incident in children under five. This finding is contrast with previous study in Indonesia which showed the significant correlation between indoor air pollution including lighting source in home, and incident of acute respiratory infection in children under five years ${ }^{18}$. A healthy housing requires sufficient light, both artificial lighting and natural lighting from the sun ${ }^{24}$.

The type of floor has no associated with acute respiratory infection in children under five and this is different from study that revealed the variable of the type of house floor which cumulatively can be interpreted to have a significant relationship between the type of floor with the incidence of acute respiratory infection in children under five ${ }^{24}$. The same thing was expressed in study in Talaud Islands Regency which proved the type of house floor affected the incidence of acute respiratory infection in children under five. As houses with ceramic or tile floor types tend to be better because they are easy to clean and not damp. Conversely, only casted floors tend to be damp, not 
waterproof, and can be a breeding ground for bacteria or viruses that cause acute respiratory infection ${ }^{25}$.

\section{Conclusion}

In the criteria for a healthy home, there is a relationship between the points of population density and smoking points in the house with the incidence of accute respiratory infection in children under five.

Funding Statement: This study has no granted funding from any institution.

Conflic of Interest: All authors declare that there is no conflict interest in this study and publication.

Acknowledgement: we would like to say thank you to Sulistiawati and Bambang $\mathrm{R}$ who have supervised us on finishing this research.

\section{References}

1. Health MO. Riset Kesehatan Dasar (Riskesdas). Minist Heal Indones. 2018;

2. Ellita. Hubungan antara Tingkat Pengetahuan Ibu dan Pemberian ASI dengan Kejadian ISPA Pada Anak balita di Rumah Sakit BLUD Ibu dan Anak di Pemerintah Aceh Tahun 2013. Universitas Aceh; 2013.

3. Kementerian Kesehatan RI. Buku Pedoman PHBS [Internet]. Kementerian Kesehatan Republic Indonesia. 2011 [cited 2019 Dec 8]. Available from: http:// promkes.kemkes.go.id/phbs

4. World Health Organization. Pencegahan dan Pengendalian ISPA. J Kesmasindo [Internet]. 2008;6:35-42. Available from: http://www.who.int/csr/ resources/publications/AMpandemicbahasa.pdf.

5. Nurjazuli WR. Faktor Risiko Dominan Kejadian pneumonia pada Anak balita. Jakarta: J Respirologi Indones. 2009;29(2).

6. Prayitno A. Hubungan Perilaku Hidup Bersih Dan Sehat Rumah Tangga Terhadap Kejadian Infeksi Saluran Pernafasan Akut Dan Diare Pada Anak Balita. Respir Unair [Internet]. 2019; Available from: http:// repository.unair.ac.id/84884/Repository.unair.ac.id.

7. Kementerian Kesehatan RI. Perilaku Mencuci Tangan Pakai Sabun di Indonesia. Jakarta; 2014.

8. Merk H, Kühlmann-Berenzon S, Linde A, Nyrén O. Associations of hand-washing frequency with incidence of acute respiratory tract infection and influenza-like illness in adults: A population-based study in Sweden. BMC Infect Dis. 2014;14(1). https://doi.org/10.1186/ 1471-2334-14-509 PMid:25234544 PMCid:PMC4 177698

9. Tomatala S, Kinasih A, Kurniasari MD, De Fretes F. Hubungan Antara Aktivitas Fisik dengan Kekambuhan ISPA Pada Anak Usia Sekolah di Kecamatan Bringin
Kabupaten Semarang. J Keperawatan Respati Yogyakarta. 2019;6(1):537. https://doi.org/10.35842/ jkry.v6i1.289

10. Purwanto. Dampak Senam Aerobik terhadap Daya Tahan Tubuh dan Penyakit. J Media Ilmu Keolahragaan Indones. 2011;1.

11. Kepmenkes RI. No: 829/MENKES/SK/VII/ 1999 tentang Persyaratan Kesehatan Perumahan. 1999.

12. Fatmawati TY. Pengaruh Pendidikan Kesehatan dengan Media Leaflet terhadap Pengetahuan Ibu tentang Penatalaksanaan ISPA pada Anak balita di Posyandu. Universitas Batanghari Jambi; 2017.

13. Direktorat Jendral P2PL. Rencana Aksi Program Pengendalian Penyakit dan Penyehatan Lingkungan tahun 2010-2014. Jakarta; 2011.

14. Lestari P. Hubungan antara Pemberian ASI Eksklusif dengan kejadian ISPA pada Anak Usia di atas 6 bulan sampai 24 bulan di Dusun Gondang, Desa Randuagung, Kecamatan Singosari, Kabupaten Malang. [Internet]. Surabaya; 2011. Available from: http://penelitian.unair.ac.id/detail_dosen_2153

15. Prameswari, G. N. Hubungan Lama Pemberian ASI Eksklusif dengan Terjadinya ISPA. Kemas [Internet]. 2009;5(1). Available from: http://journal.unnes.ac.id/ index.php/kemas

16. Endiyani B, Wawolumaja C, Pratiwi L, Ishak LM, Yasien MR, Wibiyana KA, et al. Infeksi Saluran napas Akut pada Anak balita di Daerah Urban Jakarta. Seri Pediatr [Internet]. 2009;11(4). Available from: http:// www.idai.or.id/saripediatri/pdfile/11-4-\%0A1.pdf

17. Riyanto R, Kusumawati A. Pengaruh asap rokok terhadap terjadinya penyakit ISPA pada anak balita di puskesmas Kedung Banteng Banyumas. Medisains [Internet]. 2016;14(3). Available from: http:// jurnalnasional.ump.ac.id/index.php/medi\%0Asains / artic\%OAle/view/1614

18. Hidayangsih PS, Tjandrarini DH, Nainggolan O, Sukoco NEW. The Relationship between Respiratory Infections and Healthy Homes in Children Under Five, Indonesia 2013. Media Penelit dan Pengemb Kesehat. 2017;27(3). https:/ / doi.org/10.22435/mpk.v27i3.6663.153-160

19. Mahendra IGAP, Farapti F. Relationship between Household Physical Condition with The Incedence of ARI on Todler at Surabaya. J Berk Epidemiol. 2018;6(3):227. https://doi.org/10.20473/ jbe.V6I32018.227-235

20. Department of Health in Malang. Health Profile. Malang; 2013.

21. Virarisca S, Dasuki D, Sofoewan S. Metode persalinan dan hubungannya dengan inisiasi menyusu dini di RSUP Dr. Sardjito Yogyakrta. 2019; Available from: https: / /journal.ugm.ac.id/jgki/article/view / 177\%0A44/11518 
22. Lestari RD. Analisis Persalinan Dengan Tenaga Non Kesehatan Di Wilayah Kerja Puskesmas Punggur Kabupaten Kubu Raya Tahun 2014. J proners. 2014;1(1). https://doi.org/10.30590/vol1-no2-p91-96

23. Firdaus G, Ahmad A. Relationship between housing and health: A cross-sectional study of an urban centre of India. Indoor Built Environ. 2013;22(3):498-507. https: / / doi.org/10.1177/1420326X12443846

24. Agustina, Mado FG. Analysis of Housing Environmental Factors with Arrival Disease Events in Communities in
Kelurahan Oenesu District Kupang in 2018. In: 1 international conference. Kupang: Health Polytechnic of Ministry of Health in Kupang; 2018.

25. Bee LW., Akili RH, Sinolungan JVS. Hubungan Antara Kondisi Lingkungan Fisik Rumah Dengan Kejadian Infeksi Saluran Pernapasan Akut (ISPA) Pada Anak Balita Di Wilayah Kerja Puskesmas Salibabu Kabupaten Kepulauan Talaud. Kesmas [Internet]. 2015;4(2). Available from: https://ejournal.unsrat. ac.id/ index.php/kesmas/article/view/12692. 